UDC 621.318

A. Borisova, A. Machulyansky, Ph.D., Y. Yakimenko, Dr.Sc.

National Technical University of Ukraine "Kyiv Polytechnic Institute", st. Polytechnique, 16, Kiev, 03056, Ukraine.

\title{
Analysis of Metal-dielectric Nanocomposite Coatings with Ferromagnetic Inclusions for Electromagnetic Protection of Electronic Devices
}

Metal-dielectric nanocomposite system with ferromagnetic inclusions was prepared and studied: epoxy resin-xFe ( $x=0-30 \mathrm{vol} . \%$ is a content of the Fe nanoparticles). Its dielectric and magnetic spectra were measured in a broad frequency range from $10^{6} \mathrm{~Hz}$ to $10^{10} \mathrm{~Hz}$. Both dielectric and magnetic dispersion was observed. Based on the experimental spectra of the complex permittivity and permeability, reflection and transmission coefficients of the composite layers in a free space were calculated depending on the content of ferromagnetic inclusions and layer thickness. Microwave absorption of the studied metal-dielectric composites varies in a broad rage and can be controlled by changing the concentration of ferromagnetic inclusions. The composites can be used as microwave absorbing or shielding materials. References 9, figures 3.

Keywords: metal-dielectric nanocomposites, absorbing materials, ferromagnetic inclusion, reflection loss.

\section{Introduction}

Nanocomposite metal-dielectric materials with ferromagnetic inclusions (and polymer matrix) are very interesting for a great amount of potential applications, for example: absorption of radar emission, defense from electromagnetic pulses, increase in immunity and reliability of electronic devices, electromagnetic compatibility of electronic systems, reduction of the impact on the human body etc. [1, 2]. Analysis of the electromagnetic field absorption efficiency demonstrated by present materials has showed that special attention should be paid to metal-dielectric composites based on the nanoparticles of magnetic metals distributed in dielectric matrix for developing wideband absorbing coatings [2]. It is caused by the variety of their electromagnetic properties and prospects for their application. Therefore, development and improvement of resonant devices, modern electronic and telecommunication systems is not only important task, but also motivation for the research of absorbing materials based on composite metal-dielectric systems (CMDS). However, development of such metal-dielectric composites with the specified spectral parameters is very complicated task, since even minor change in content and structure of composite materials leads to significant change of their electromagnetic properties [2]. Moreover, existing descriptions of such electrodynamics parameters as dielectric permittivity and magnetic permeability, depending on the structure and content of nanocomposite components, are not enough developed and are given only for narrow frequency range [2, 3]. Accordingly, the comprehensive analysis of absorbing materials based on CMDS in a wide frequency range is the actual problem.

Continuing previously performed experiments [4-6], the current work reports on the study of dielectric $\left(10^{-2}\right.$ to $\left.10^{10} \mathrm{~Hz}\right)$ and magnetic $\left(10^{6}\right.$ to $10^{10}$ $\mathrm{Hz}$ ) spectra of the epoxy resin - Fe composites and on the analysis of their microwave absorbing and shielding efficiency.

\section{Processing and Experimental Techniques}

Samples of metal-dielectric composite materials were produced by the electromechanical mixing of nanodispersed metal filler with the binding matrix material at room temperature. The nanodispersed powder of Fe was used as metal filler and the epoxy resin as a dielectric matrix. Series of epoxy resin-xFe ( $x=0-30$ vol. \% is a content of the $\mathrm{Fe}$ nanoparticles) compositions was prepared. The structure of the composite materials was investigated by a raster electronic microscopy. It is seen from the results of electronic microscopy studies, that nanodispersed metal phase is represented by the particles from $50 \mathrm{~nm}$ to $100 \mathrm{~nm}$ in size.

Samples of two kinds were prepared for dielectric experiments. Plate-shaped samples (with a diameter of $10-20 \mathrm{~mm}$ and thickness of $3-5 \mathrm{~mm}$ ) were used in the low-frequency (LF, $\left.10^{-2}-10^{6} \mathrm{~Hz}\right)$ and microwave (MW, $10^{8}-10^{10} \mathrm{~Hz}$ ) measurements. For the high-frequency $\left(\mathrm{HF}, 10^{6}-10^{9} \mathrm{~Hz}\right)$ measurements, cylindrical samples with a diameter of 2-3 $\mathrm{mm}$ and length of 5-7 $\mathrm{mm}$ were prepared. In LF and HF experiments, the pasted silver or evaporated gold electrodes were deposited on the flat 
surfaces of samples, while the MW experiment was performed on samples without electrodes. For the magnetic experiment, toroid-like samples with outer diameter of $7-8 \mathrm{~mm}$, inner diameter of $\sim 3.5 \mathrm{~mm}$ and thickness of 2-3 mm.

Dielectric and ac conductivity spectra were measured using impedance methods by the techniques described in $[7,8]$. Standard LF dielectric measurements were performed with the dielectric analyzer Novocontrol Alpha AN, HF measurements - with the Novocontrol BDS 2100 coaxial sample cell and Agilent 4291B impedance analyzer, MW measurements - with the open-end coaxial probe and Agilent E8364B vector network analyzer. Magnetic spectra were measured by the impedance method with Agilent E5061B-3L5 network analyzer and Agilent 16454A magnetic material test fixture.

\section{Results and Discussion}

Experimentally measured spectra of the real $\mu^{\prime}$ and imaginary $\mu$ " parts of the complex magnetic permeability of the epoxy resin - Fe composites are presented in Figure 1, and the broadband spectra of the dielectric permittivity and conductivity are shown in [5].

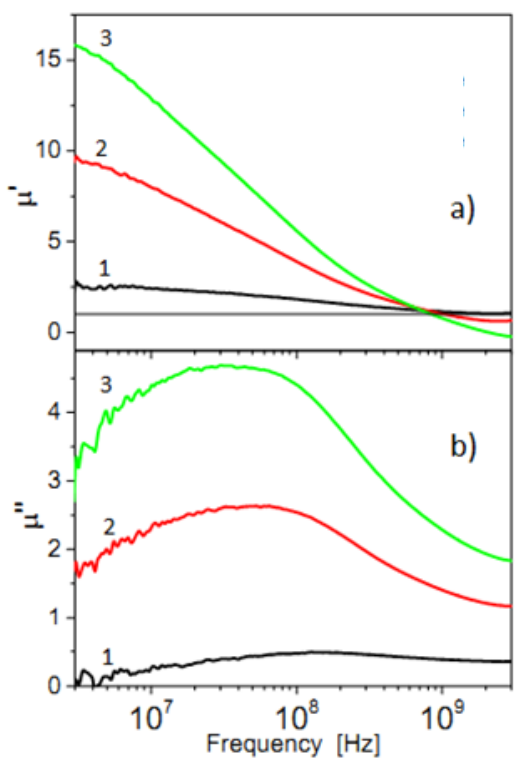

Fig. 1. Frequency dependence of the real (a) and imaginary (b) parts of the complex magnetic permeability of the epoxy - xFe composites with different concentrations of $\mathrm{Fe}$ (in vol. $\%$ ) $1-x=10 ; 2-x=20$; $3-x=30$
For all studied compositions, dielectric and magnetic dispersion was observed in the whole studied frequency range.

Generally, the increase in concentration of ferromagnetic inclusions leads to an increase in the values of both dielectric permittivity and magnetic permeability at all frequencies. Some deviations of dielectric parameters from the monotonic dependence on concentration observed in [5] could be caused by nonuniform distribution of ferromagnetic nanoparticles in a dielectric matrix. Let us note, that magnetic properties of the composites are less dependent on the filler distribution and are mainly determined by the filler concentration.

High dielectric and magnetic losses of the epoxy resin - Fe composites observed in the highfrequency and microwave ranges (see Fig. 1 and [5]) are very important for their tentative application as absorbing or shielding materials.

Microwave absorbing efficiency of nanocomposites can be estimated using the freespace model presented in Figure 2 [9]. It shows a multilayer microwave absorber that consists of $n$ layers of different materials backed by a perfect electric conductor. For simplicity, the normally incident electromagnetic wave is considered.

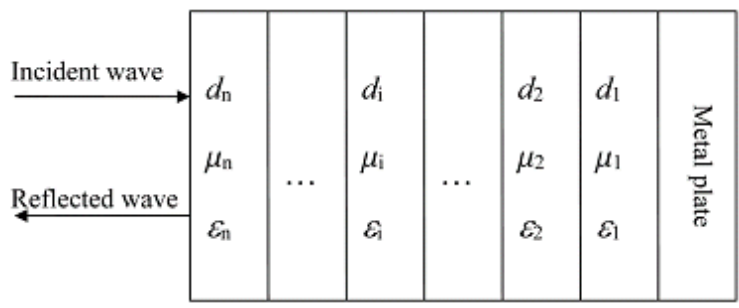

Fig. 2. Schematic of a multilayer microwave absorber with a normally incident wave. di, $\mu \mathrm{i}$, and $\varepsilon i$ denotes the thickness, complex magnetic permeability and permittivity of the i-th layer, respectively [9]

In the case of a single layer absorber backed by a perfect electric conductor, the reflection loss $(R L)$ of the absorber and attenuation constant $\alpha$ (real part of the propagation constant $\mathrm{y}$ ) of the material, in nepers $/ \mathrm{m}$, can be calculated as following [9]:

$$
R L=20 \log |\Gamma|=20 \log \left|\frac{Z_{n}+\eta_{0}}{Z_{n}-\eta_{0}}\right|
$$




$$
R L=20 \log \left|\frac{\sqrt{\frac{\mu}{\varepsilon}} \tanh \left(\mathrm{j} \frac{2 \pi f d}{c} \sqrt{\mu \varepsilon}\right)+1}{\sqrt{\frac{\varepsilon}{\mu}} \tanh \left(\mathrm{j} \frac{2 \pi f d}{c} \sqrt{\mu \varepsilon}\right)-1}\right|
$$

where $\varepsilon=\varepsilon^{\prime}-i \varepsilon^{\prime \prime}$ is a complex permittivity and $\mu=\mu^{\prime}+i \mu^{\prime \prime}$ is a complex permeability of the material, $d$ is the layer thickness and $c$ is a velocity of the electromagnetic wave.

We used our experimentally measured spectra of the complex permittivity and permeability to calculate the reflection loss and attenuation constant spectra of single layer absorbers with different thicknes based on the composites of epoxy resin with different concentration of $\mathrm{Fe}$ nanoparticles. The results are presented in Figures 3,4 .

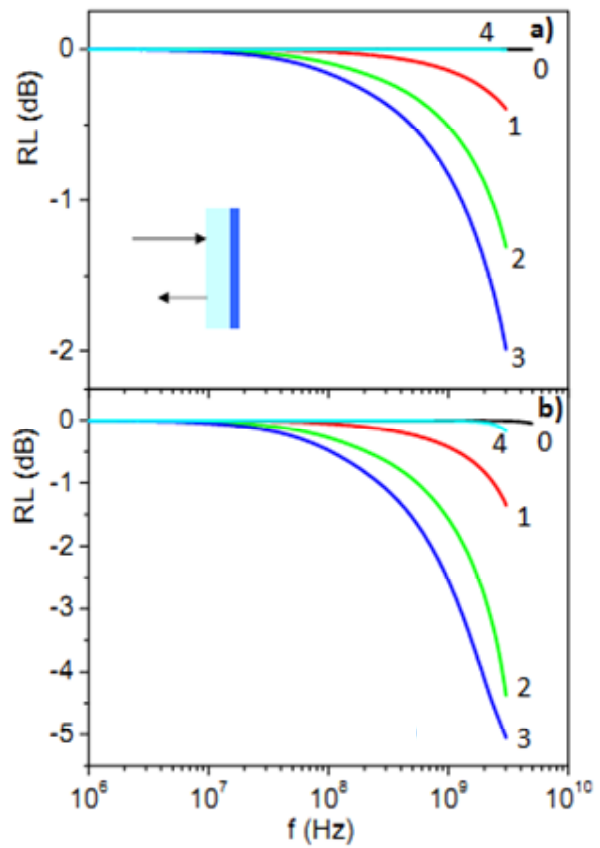

Fig. 3 Frequency dependence of the reflection loss (RL) for the epoxy - xFe composites with different concentration of $\mathrm{Fe}$ (in vol. \%) $0-x=0 ; 1-x=10,2-x$ $=20,3-x=30,4-x=30(\mu=1)$ for the layer thickness of $1 \mathrm{~mm} \mathrm{(a)}$ and $3 \mathrm{~mm} \mathrm{(b)}$

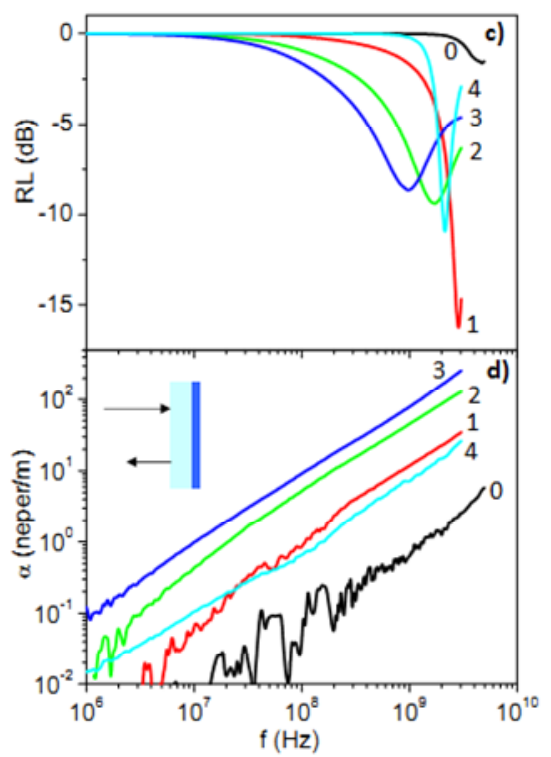

Fig. 4. Frequency dependence of the reflection loss (RL) (c) and the attenuation constant $\alpha$ (d) for the epoxy - xFe composites with different concentration of Fe (in vol.\%): $0-x=0 ; 1-x=10,2-x=20,3-x$ $=30,4-x=30(\mu=1)$ for the layer thickness of 10 $\mathrm{mm}$

Analysis of the dependences given in Figures 3 and 4 shows that variation of $\mathrm{Fe}$ content from 0 to $30 \mathrm{vol}$. \% causes changes in the reflection losses up to $20 \mathrm{~dB}$ at frequency range from 1 to $3 \mathrm{GHz}$, depending on the layer thickness. At the same time the attenuation constant reaches 100 neper/m. Importance of the magnetic properties is clearly shown by comparison of curves 3 and 4 (in Figures 3 and 4). Both curves correspond to the same composition $(x=30)$ with the same dielectric parameters, but in the case of curve 4 magnetic properties were neglected in calculations.

Reflection loss and attenuation constant characterize the microwave absorption (MA) efficiency which could be numerically estimated as $M A=-R L$ [9]. Then increasing of complex magnetic permeability allows to expand the MA band, by shifting it toward lower frequencies. 


\section{Conclusions}

Microwave absorption of the studied metaldielectric composites varies in a broad rage (from 0 $\mathrm{dB}$ to $20 \mathrm{~dB}$ ) in the wide frequency range (107 $1010 \mathrm{~Hz}$ ) and can be controlled by changing the concentration of ferromagnetic nanoparticles and the thickness of the layer. Studied composites can be used as microwave absorbing or shielding materials.

\section{References}

1. Henry W. Ott. (2009), "Electromagnetic Compatibility Engineering." New York, I. Wiley \& Sons, P. 862.

2. Machulyanskii A.V., Pilinskii V.V., Telichkina O.V., et al, (2010), "Osnovy primeneniya nanostrukturnykh materialov dlya obospecheniya elektromagnitnoi sovmestimosti elektronnykh ustroistv [Basis for the use of nanostructured materials for electromagnetic compatibility of electronic devices]". Elektronika i svjaz', No 3, pp.9-15 (Rus.).

3. Pomogailo A. D., Rozenberg A. S., Uflyand I. E. (2000)," Nanochastitsy metallov v polimerakh. [Metal nano-particles in polymers]".Moskva, Khimiya, P. 672. (Rus.).

4. Machuliansky Aleksandr, Pilinsky Vladimir, Telychkina Oksana, Rodionova Maria, Joskiewicz Zbigniew M., Wieckowski Tadeusz W. (2010), "Application of Nanostructured Materials Ensuring the Electromagnetic Compatibility of Power Electronic". Int. Symposium EMC Europe, (1317 September, 2010),Wroclaw, Poland, 2010, pp.814-817.
5. Borisova A., Machulyansky A., Yakimenko Y., Bovtun V., Kempa M., Savinov M. (2013), "Broadband dielectric and conductivity spectra of dielectric-metal nanocomposites for microwave applications". 201333 Int. Scintific Conf "Elektronics and nanotechnology" (ELNANO), Kiev, 2013, pp. 21-24.

6. Borisova A.V., Bovtun V., Machulyansky A.V., Kempa M., Yakimenko Yu.l. (2013), "Electrodynamic characteristics of metal-dielectric nanocomposites with ferromagnetic inclusions". 23th Int. Crimean Conf "Microwave \& Telecommunication Technology" (CriMiCo' 2013), Sevastopol, 2013. pp.783-784.

7. D. Nuzhnyy., P. Vaněk, J. Petzelt, V. Bovtun, M. Kempa, I. Gregora, M. Savinov, $R$. Krupková, V. Studnička, J. Buršík, M. I. Samoylovich, W. Schranz. (2010), "Properties of BaTiO3 confined in nanoporous Vycor and artificial opal silica". Processing and Application of Ceramics 4 [3], 215-223.

8. D. Nuzhnyy, J. Petzelt, V. Bovtun, M. Kempa, M. Savinov, C. Elissalde, U.-C. Chung, D. Michau, C. Estournès, and M. Maglione. (2011), "High-Frequency Dielectric Spectroscopy of BaTiO3 Core - Silica Shell Nanocomposites: Problem of Interdiffusion". Journal of Advanced Dielectrics 1, No. 3, 309-317.

9. F. Qin, C. Brosseau, J. Appl. Phys. 121, 061901 (2011).

Поступила в редакцию 15 сентября 2014 г.

УДК 621.318

О.В. Борисова, О.В. Мачулянський , канд. техн. наук, Ю.І. Якименко, д-р. техн. наук Національний технічний університет України "Київський політехнічний інститут", вул. Політехнічна, 16, корпус 12, Київ, 03056, Україна.

\section{Аналіз металодіелектричних нанокомпозитних покриттів на основі феромагнітних включень для електромагнітного захисту електронних пристроїв}

Виготовлено та досліджено металодіелектричні нанокомпозитні системи на основі фреромагнитних включень: епоксидна матриця- хFe (вміст часточок Fe $x=0-30$ об'ємных \%). Проведено дослідження діелектричної та магнітної проникливості в широкому діапазоні частот (від 106 Ги до 1010 Ги). Отримані дисперсійні залежності. Розраховані на основі експериментальних даних коефіцієнти відбиття та проходження покриттів в залежності від концентрації феромагнітних включень та товщини шару. Показано, що електромагнітними властивостями

(C) Borisova A., Machulyansky A., Yakimenko Y., 2014 
металодіелектричних нанокомпозитних систем в НВч діапазоні можна керувати, змінюючи концентрацію металевих включень. Надано рекомендації щодо використання металодіелектричних нанокомпозитних систем на основі фреромагнитних включень в якості екрануючих в НВЧ діапазоні покриттів. Бібл. 9, рис. 4.

Ключові слова: металлодіелектричні нанокомпозити, поглинаючі матеріали, фрерромагні включення, втрати на відбиття.

УДК 621.318

А.В. Борисова, А.В. Мачулянский, канд. техн. наук, Ю.И. Якименко, д-р. техн. наук Национальный технический университет Украины «Киевский политехнический институт», ул. Политехническая, 16, корпус 12, г. Киев, 03056, Украина.

\section{Анализ металло-диэлектрических нанокомпозитных покрытий на основе ферромагнитных включений для электромагнитной защиты электронных устройств}

Подготовлены и изучены нанокомпозитные металлодиэлектрические системы на основе ферромагнитных включений: эпоксидная матрица-хFe (содержание частиц $\mathrm{Fe} x=0-30$ объемных \%). Проведено исследование диэлектрической и магнитной проницаемости в широком диапазоне частот (от 106 Ги до 1010 Ги). Получены дисперсионные зависимости. Рассчитаны на основе экспериментальных данных коэфффициенты отражения и прохождения покрытий в зависимости от концентрации фрерромагнитных включений и толщины слоя. Показано, что электромагнитными свойствами металлодиэлектрических нанокомпозитных систем в СВЧ диапазоне можно управлять путем изменения концентрации металлических включений. Даны рекомендации по использованию металлодиэлектрических нанокомпозитных систем на основе фрерромагнитных включений в качестве экранирующих в СВЧ диапазоне покрытий. Библ . 9, рис. 4.

Ключевые слова: металлодиэлектрические нанокомпозиты, поглощающие материалы, фрерромагнитные включения, потери на отражение.

\section{Список использованных источников}

1. Henry W. Ott. Electromagnetic Compatibility Engineering. - New York, I. Wiley \& Sons, 2009. - 862 p.

2. Мачулянский А.В., Пилинский В.В., Теличкина О.В. Основы применения наноструктурных материалов для обеспечения электромагнитной совместимости электронных устройств. Электроника и связь. - 2010. - № 3. - С. 9-15.

3. Помогайло А.Д., Розенберг А.С., Уфлянд И.Е. Наночастицы металов в полимерах. - М.: Химия, 2000. - 672 c.

4. Machuliansky A., Pilinsky V., Telychkina O., Rodionova M., Joskiewicz Zbigniew M., Wieckowski Tadeusz W. Application of Nanostructured Materials Ensuring the Electromagnetic Compatibility of Power Electronic. Int. Symposium EMC Europe, 2010 (13-17 September, 2010), Wroclaw, Poland, 2010, - pp. 814-817.

5. Borisova A., Machulyansky A., Yakimenko Yu., Bovtun V., Kempa M., Savinov M. Broadband dielectric and conductivity spectra of dielectric-metal nanocomposites for microwave applications. 201333 Int. Scintific Conf "Elektronics and nanotechnology" (ELNANO), Kiev, 2013, - pp. 21-24.

6. Borisova A., Bovtun V., Machulyansky A., Kempa M., Yakimenko Yu. Electrodynamic characteristics of metal-dielectric nanocomposites with ferromagnetic inclusions. 23th Int. Crimean Conf "Microwave \& Telecommunication Technology" (CriMiCo' 2013), Sevastopol, 2013. - pp. 783-784.

7. Nuzhnyy D., Vaněk P., Petzelt J., Bovtun V., Kempa M., Gregora I., Savinov M., Krupková R., Studnička V., Buršík J., Samoylovich M., Schranz W. Properties of BaTiO3 confined in nanoporous Vycor and artificial opal silica. Processing and Application of Ceramics 4 [3], 215-223 (2010).

8. Nuzhnyy D., Petzelt J., Bovtun V., Kempa M., Savinov M., Elissalde C., Chung U.-C., Michau D., Estournès C., Maglione M. High-Frequency Dielectric Spectroscopy of BaTiO3 Core - Silica Shell Nanocomposites: Problem of Interdiffusion. Journal of Advanced Dielectrics 1, No. 3, 309-317 (2011).

9. Qin F., Brosseau C., Appl J. Phys. 121, 061901 (2011). 